\title{
Characterization of proteins in cryopreserved and non-cryopreserved seminal plasma of dairy bulls of differing fertility
}

\author{
Seminal plasma proteomics \\ J. F. Odhiambo ${ }^{1,2}$, R. A. Dailey ${ }^{1^{*}}$ \\ ${ }^{1}$ Division of Animal and Nutritional Sciences, West Virginia University, Morgantown, USA; ${ }^{*}$ Corresponding Author: rdailey@,wvu.edu \\ ${ }^{2}$ Department of Agricultural, Food and Nutritional Science, University of Alberta, Edmonton, Canada;
}

Received 6 May 2011, revised 25 May 2011, accepted 10 June 2011.

\begin{abstract}
Seminal plasma is composed of secretions from accessory sex glands, which are mixed with sperm at ejaculation and contribute the majority of semen volume. Seminal plasma is considered a transport and support medium for sperm in the female reproductive tract. Because seminal plasma is not required for fertilization, the importance of its constituents to the establishment of normal pregnancy has been overlooked. Four seminal plasma proteins, Osteopontin, Spermadhesin Z13, BSP $30 \mathrm{kDa}$ and Phospholipase A2, have been identified as markers of fertility in dairy bulls [1-3]. The objective of the present study was to characterize the expression patterns of these proteins and other proteins found to be of interest in seminal plasma of cryopreserved and non-cryopreserved bull semen. Seminal plasma samples were obtained from 16 mature Holstein- Friesian bulls at Select Sires Inc. Samples were divided into two groups based on assigned fertility score expressed as the percentage point deviation (PD) of the bull's non-return rate (NRR) from the average NRR of all bulls in the Select Sires Inc. reproductive management program. Group 1 (high fertility bulls, $n=8$ ) $1.9 \% \leq P D \leq 2.7 \%$, and group 2 (low fertility bulls, $n=8)-6.5 \% \leq$ PD $\leq 1.8 \%$. Additionally, the samples were categorized as processed (cryopreserved) or unprocessed (noncryopreserved) for protein analysis. Protein expression was analyzed by 2 - D fluorescence difference gel electrophoresis (2D-DIGE ${ }^{\mathrm{TM}}$ ). Protein spots were picked from a reference gel, analyzed by mass spectrometry and, subsequently identified by MS/MS ion searches performed on the SwissProt database. Protein ex-
\end{abstract}

pression did not differ $(P>0.05)$ with fertility grouping but displayed two distinct pa- tterns among the processing groups: majority of the functional proteins were highly expressed in seminal plasma of non-cryopreserved semen while the cryopreserved semen contained mainly structural/ extender derived proteins. Functional proteins identified included Spermadhesin Z13, BSP A1/2, BSP $30 \mathrm{kDa}$, Nucleobindin-1 and metalloproteinase inhibitor 2. Some of these proteins have been identified as anti-fertility or fertility enhancing agents in males. Whether this alteration in protein expression after processing might affect semen fertility is worthy of further evaluation.

Keywords: Seminal Plasma; Proteomics; Bull Fertility

\section{INTRODUCTION}

Secretions from the accessory sex glands are mixed with sperm at ejaculation and contribute to the majority of semen volume and components. However, during cryopreservation, most seminal plasma is replaced with semen extenders, mainly egg yolk or milk proteins. Seminal fluid contains signaling agents that influence female reproductive physiology to improve chances of conception and pregnancy success. These factors include cytokines, sex hormones, and prostaglandins [4]. Experiments in rodents and pigs showed that seminal plasma is the second most vital component of the ejaculate, absence of which at mating reduced fertilization and increased fetal loss after implantation [5]. Artificial inseminations with adjunctive seminal plasma consistently tended to have little or no effect on pregnancy outcome [6]. The precise nature of active constituents 
that might influence pregnancy and their relative amounts remain relatively unknown.

High concentrations of TGF- $\beta$ cytokines were detected in boar seminal fluid [7], and their characteristic immunosuppressive activity was associated with protein fractions of appropriate size in boar seminal fluid [4]. Four proteins (osteopontin, spermadhesin Z13, bovine seminal plasma protein (BSP) $30 \mathrm{kDa}$, and phospholipase $A_{2}$ ) were identified as markers of fertility in dairy bulls [1-3]. In those studies, proteins were visualized with Coomassie brilliant blue staining after 2-D gel separation, a process that might not reveal some of the low abundance proteins in seminal plasma that might be of biologic importance.

Therefore, a more sensitive protein detection technique that would give a broader approach was used in the present study to identify seminal plasma proteins. The multiplexing capability of 2 - D fluorescence difference gel electrophoresis (2 - D DIGE) technology was expected to broaden the number of markers included in the assay and yield more robust predictions of biomarkers for bull fertility. The objectives of this study included: 1) large scale identification and differential expression of seminal plasma proteins between high and low fertility bulls, 2) correlation of expression of specific proteins to fertility phenotype, and 3) comparison of the expression patterns pre- and post-cryopreservation.

\section{MATERIALS AND METHODS}

Semen samples from 16 dairy bulls were obtained from Select Sires Inc. (Plain City, Ohio). All samples used (cryopreserved and non-cryopreserved) were obtained from the same ejaculate of each bull and processed at Select Sires Inc. At each collection time, ejaculates from the same bull were pooled and an aliquot was obtained for the non-cryopreserved sample. The rest of the semen was processed and extended for cryopreservation in $0.5 \mathrm{~mL}$ semen straws.

Semen was extended in egg-yolk-citrate (EYC) composed of a $2.9 \%$ sodium citrate buffer supplemented with $20 \%$ egg yolk ( $\mathrm{vol} / \mathrm{vol})$ prepared with a glycerolated and non-glycerolated fractions containing 14 or $0 \%$ glycerol (vol/vol), respectively. Samples were diluted 1:3 (vol/vol) with non-glycerolated semen extender, placed in a $200-\mathrm{mL}$ water bath and allowed to equilibrate to $5^{\circ} \mathrm{C}$ over a 2 -h period. Samples were extended to half volume $(80 \times 106 / \mathrm{ml})$ in non-glycerolated extender and then an equal volume of glycerolated extender was slowly titrated over a 10 min period. The final dilution yielded a sperm concentration of $20 \times 106$ per $0.5-\mathrm{mL}$ French straw. Straws were then frozen in liquid nitrogen. To obtain seminal plasma, semen was centrifuged at 3,000 $\mathrm{g}$ for $10 \mathrm{~min}$ and then aspirated into Eppendorf

Copyright $\odot 2011$ SciRes. tubes for volumes $<1 \mathrm{~mL}$, or $15 \mathrm{~mL}$ centrifuge tubes for larger volumes. Samples were then further clarified in 0.45 micron syringe filter and finally frozen in $0.5 \mathrm{~mL}$ straws.

Samples were assigned to high or low fertility groups based on fertility score expressed as the percentage point deviation (PD) of the bull's non-return rate (NRR) from the average NRR of all bulls in the Select Sires Inc. reproductive management program. These scores were based on inseminations with frozen semen from the bulls under this program. Range of scores for high fertility bulls $(n=8)$ was $1.9 \% \leq \mathrm{PD} \leq 2.7 \%$ and for low fertility bulls $(n=8)$ was $-6.5 \% \leq \mathrm{PD} \leq 1.8 \%$.

Following delivery, semen samples were thawed at room temperature and centrifuged at $10,000 \times \mathrm{g}$ for 15 $\min$ at $4{ }^{\circ} \mathrm{C}$ to remove sperm and associated debris. Aliquots of $0.5 \mathrm{~mL}$ seminal samples were obtained from the supernatant and stored frozen at $-80^{\circ} \mathrm{C}$ until further use.

\subsection{Electrophoresis}

Frozen samples of seminal plasma were thawed at room temperature and centrifuged at $10,000 \times \mathrm{g}$ for 60 $\min$ at $4^{\circ} \mathrm{C}$. The supernatant was processed by 2-D Clean-UP protocol (GE Healthcare, Piscataway, NJ) to remove impurities such as nucleic acids, lipids and salts. Samples were then assayed for protein content [8] using BSA as standard, and aliquots were frozen at $-800^{\circ} \mathrm{C}$. Samples for electrophoresis were thawed at room temperature, concentrated to $1-10 \mathrm{mg}$ protein $/ \mathrm{mL}$ and labeled with cyanine dye (CyDye) DIGE Fluor Cy3/5 (GE Healthcare, Piscataway, NJ) at a ratio of $50 \mu \mathrm{g}$ protein to 400 pmol fluor. A pooled internal standard was created from equal aliquots of each sample and labeled with Cy2 dye. Samples were separated by isoelectric focusing on an Ettan ${ }^{\mathrm{TM}}$ IPGphor ${ }^{\mathrm{TM}}$ apparatus (GE Healthcare, Piscataway, NJ) using $24 \mathrm{~cm}$ Immobiline DryStrip gels (GE Healthcare, Piscataway, NJ) containing a mixture of ampholytes with $\mathrm{pH}$ ranging from 3 to 10 .

Following isoelectric focusing, strip gels were transferred to $24 \mathrm{~cm}$ Tris-Tricine gradient gels (Bio-Rad Laboratories, Hercules, CA) mounted on low-fluorescence glass plates. Thereafter, proteins were separated by molecular mass in the second dimension using Ettan ${ }^{\mathrm{TM}}$ Dalt II Electrophoresis System (GE Healthcare, Piscataway, NJ). Dalt gels were scanned using a Typhoon 9400 Variable Mode imaging densitometer (GE Healthcare, Piscataway, NJ) at $100 \mu \mathrm{m}$ resolution. A fully automated image analysis software, Progenesis SameSpots ${ }^{\mathrm{TM}}$ (Nonlinear Dynamics, Durham, NC), was used to analyze the protein expression data.

\subsection{Statistical Analysis}

In 2D-DIGE experiments, the pooled internal stan- 
dards were essential for assessing biological and experimental (between gels) variations and increasing the robustness of statistical analysis. Individual protein data from sample groups (Cy3 or Cy5) were normalized against the Cy2 labeled internal standard. Scanned images of the labeled proteins were sequentially analyzed by differential in-gel analysis (DIA) that performed $\mathrm{Cy} 3 / \mathrm{Cy} 5: \mathrm{Cy} 2$ normalization, and then by biological variation analysis (BVA) that performed inter-gel statistical analysis to provide relative abundance in various groups. Log abundance ratios were then compared between sample groups using ANOVA and t-test in Progenesis SameSpots. The analyzed spots were ranked by their probability values and then grouped into experimental groups for further evaluation. Principal component analysis (PCA) was used to determine the presence of outliers in the data and also to compare how well the samples fitted to the experimental groups. The expression profiles of the selected proteins were then examined by correlation analysis.

\subsection{Protein Identification}

A list of protein spots of interest (pick-list) was generated using the image analysis software and exported directly into a Spot Picking Ettan ${ }^{\mathrm{TM}}$ Spot Handling Workstation (GE Healthcare, Piscataway, NJ) equipped to automatically pick spots from the Dalt gels. Selected protein spots were washed by $50 \mathrm{mM}$ ammonium bicarbonate $/ 50 \%$ ( vol $/ \mathrm{vol})$ methanol in water, dried by vacuum centrifugation, and incubated overnight at $370 \mathrm{C}$ in $140 \mathrm{ng}$ of sequencing grade trypsin [9]. Tryptic digests were analyzed by capillary liquid chromatographynanoelectrospray ionization-tandem mass spectrometry (CapLC-MS/MS, Thermo Finnigan, San Jose, CA). Proteins were identified by MS/MS ion searches performed on the processed spectra against the SwissProt and NCBI protein databases using a Bioworks Browser 3.1 (Thermo Finnigan, San Jose, CA) search engine. The identification of a protein was confirmed when the Bioworks confidence interval was greater than $95 \%$. The protein mass and $\mathrm{pI}$ accuracy on the $2 \mathrm{D}$ gel was used as a guide to confirm protein identification.

\section{RESULTS}

\subsection{Distribution of Protein Spots in Seminal Plasma of Dairy Bulls}

Three patterns of protein expression were observed consistently in seminal plasma samples of cryopreserved semen (Figure 1). Spot volume analysis and peptide identification indicated a higher expression of proteins from semen extender at the molecular weight range between 30 to $60 \mathrm{kDa}$ (Group 1) accounting for $55 \%$ of protein spots by Coomassie staining. A "train" of spots was visible within the 20 to $25 \mathrm{kDa}$ range (Group 2) accounting for about $35 \%$ of the spot volume, while the remaining spots $(10 \%)$ were expressed below the $20 \mathrm{kDa}$ range (Group 3).

There was a two-fold difference $(P<0.01)$ in total protein content between extended and non-extended seminal plasma ( $41.6 \pm 2.3$ vs. $19.5 \pm 2.1 \mathrm{ng} / \mathrm{mL}$, respectively). However, the expression patterns of proteins in seminal plasma of high and low fertility bulls did not differ $(P>0.05)$. Therefore, subsequent analyses were done between cryopreserved (processed) and non-cryopreserved (unprocessed) seminal plasma. A total of 54 spots differed $(P<0.001)$ in expression pattern between processed and unprocessed seminal plasma (Figure 2(a)). The spots were then examined by principal component analysis and clustered into two groups: those 31 spots $(57.4 \%)$ that were highly expressed in processed seminal plasma but not in unprocessed seminal plasma and those 23 spots $(42.6 \%)$ that were highly expressed in unprocessed seminal plasma but not in processed seminal plasma (Figure 2(b)).

\subsection{Protein Identification}

A reference image (Figure 3) was generated from the expression data and used to pick spots for protein identification (Table 1). Extender derived proteins, mainly chicken vitellogenin-2 (MW $20.5 \mathrm{kDa}$ ), fibrinogen $\beta$ chain (MW 52.70) and chicken albumin, were predominant proteins identified from spots above $20 \mathrm{kDa}$ in seminal plasma of processed semen. In unprocessed seminal plasma, which lacked extender proteins, several spots above $20 \mathrm{kDa}$ were identified. Notable among these proteins were nucleobindin-1, clusterin, phospholipase A2 isoforms, seminal plasma protein BSP-30 kDa, metalloproteinase inhibitor-2 and cathepsins (B and D). Below $20 \mathrm{kDa}$ range, greater amounts of spermadhesin (SPAD1 and Z13) isoforms were expressed than the major bovine seminal plasma proteins (PDC - 109 and BSP-A3) in seminal plasma of processed semen. However, in unprocessed seminal plasma, PDC - 109 and BSP-A3 predominated over the spermadhesins below the $20 \mathrm{kDa}$ range.

\section{DISCUSSION}

The main finding of this study was that expression pattern of seminal plasma proteins differed between, cryopreserved and non-cryopreserved dairy bull semen. Indeed, during cryopreservation, major seminal plasma proteins are replaced with extender proteins. Most artificial inseminations in cattle involve use of processed (cryopreserved) semen, and as a consequence, most fertility data have been derived from inseminations with 
Table 1. Proteins identified from corresponding spots in Figure 3.

\begin{tabular}{|c|c|c|c|c|c|c|}
\hline Gel ID & Fold increase $^{*}$ & Protein ID & Accession number & Coverage \% & $\begin{array}{c}\text { Molecular } \\
\text { weight }\end{array}$ & pI \\
\hline \multicolumn{7}{|c|}{ Membrane stabilizing proteins } \\
\hline 1 & 95.4 & Spermadhesin Z13 & P82292 & 44.0 & 15.2 & 6.3 \\
\hline 19 & 30.2 & Spermadhesin Z13 & P82292 & 43.3 & 15.2 & 6.3 \\
\hline 3 & 54.4 & Spermadhesin 1 & P29392 & 78.4 & 15 & 5.1 \\
\hline 20 & 30.1 & $\begin{array}{l}\text { Epididymal secretory pro- } \\
\text { tein E1 }\end{array}$ & P79345 & 55.0 & 16.6 & 8.4 \\
\hline \multicolumn{7}{|c|}{ ECM interacting proteins } \\
\hline 6 & 38.8 & Cathepsin B & P07688 & 16.1 & 36.7 & -- \\
\hline 26 & 27.3 & Cathepsin D & P80209 & 5.1 & 42.5 & -- \\
\hline 43 & 20.4 & Clusterin & P17697 & 31.4 & 51.1 & 6.0 \\
\hline 12 & 33.9 & $\begin{array}{c}\text { Metalloproteinase inhibitor } \\
2\end{array}$ & P16368 & 42.7 & 24.3 & 7.8 \\
\hline \multicolumn{7}{|c|}{ Capacitation/acrosome reaction proteins } \\
\hline 9 & 37.3 & BSP-A1/A2 & P02784 & 44.8 & 15.5 & 4.9 \\
\hline 19 & 30.2 & $\mathrm{BSP} \mathrm{A} 1 / \mathrm{A} 2^{\dagger}$ & P02784 & 44.8 & 15.5 & 4.9 \\
\hline 34 & 24.6 & BSP-30kDa & P81019 & 27.9 & 21.3 & 5.9 \\
\hline 51 & 17.1 & Phospholipase A2 & IPI00760435.1 & 47.1 & 50.1 & 6.5 \\
\hline 90 & 7.9 & $\begin{array}{l}\text { Platelet-activating factor } \\
\text { acetylhydrolase }\end{array}$ & Q28017 & 53.2 & 50.1 & 6.5 \\
\hline 100 & 5.5 & Nucleobindin-1 & Q0P569 & 63.1 & 54.9 & 5.2 \\
\hline \multicolumn{7}{|c|}{ Ubiquitination proteins } \\
\hline 14 & 33.3 & Kelch-like protein 9 & Q2T9Z7 & 24.5 & 153.6 & 8.8 \\
\hline \multicolumn{7}{|c|}{ Motility associated proteins } \\
\hline 30 & 26.4 & $\begin{array}{c}\text { Fast myosin heavy chain } \\
\text { extraocular }\end{array}$ & IPI00829549.2 & 30.6 & 186.1 & 5.7 \\
\hline
\end{tabular}

*Spot volumes differed in relative amounts compared to internal standard; ${ }^{\dagger}$ Protein was identified at this spot only in unprocessed semen.; ${ }^{\dagger}$ Identification at this spot was enhanced by semen processing.

processed semen. Therefore, it was prudent to utilize cryopreserved semen in this study to examine changes in its protein profile between low and high fertile bulls, and also between processed and unprocessed semen.

Abundant low molecular weight bovine seminal plasma proteins were replaced during cryopreservation by high molecular weight extender-derived chicken structural proteins. Major bovine seminal plasma proteins PDC-109 (BSP-A1/A2), BSP-A3 and BSP-30 kDa play important roles in fertility by maintaining sperm in an appropriate state in the female tract until the oocyte reaches the site of fertilization [10-13]. It is unclear whether the effect of processing that decreased the ab-

\section{Copyright () 2011 SciRes.}

undance of these BSP proteins by more than half would render them ineffective in preventing premature capacitation and acrosome reaction of sperm from normal fertility bulls in the female tract. Spot volume data indicated that removal of the major seminal plasma proteins exposed less abundant low molecular weight proteins like spermadhesins, especially spermadhesin Z 13 which has been identified as an antifertility factor $[2,14]$ in bovine semi-nal plasma.

Killian et al. [14] suggested that four bovine seminal plasma proteins were associated with fertility. These proteins were later characterized as osteopontin and BSP-30 $\mathrm{kDa}$ in high fertility bulls and spermadhesin $\mathrm{Z}$ 


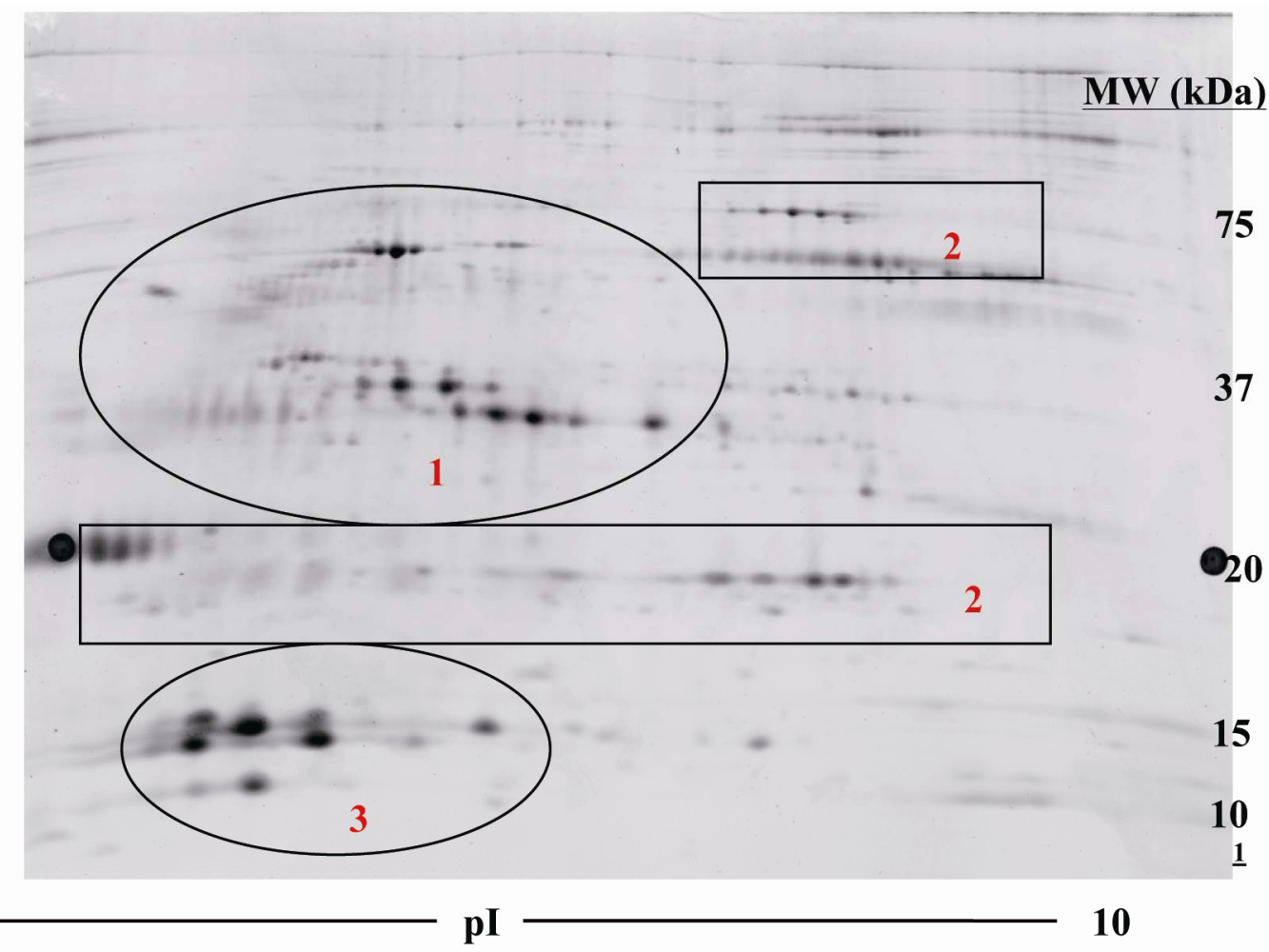

Figure 1. Reference 2D gel depicting distribution of protein spots in seminal plasma of dairy bulls. Protein spots were characterized as: 1) probable extender-derived proteins, 2) probable medium and high molecular weight seminal plasma proteins, and 3) major bovine seminal plasma proteins.

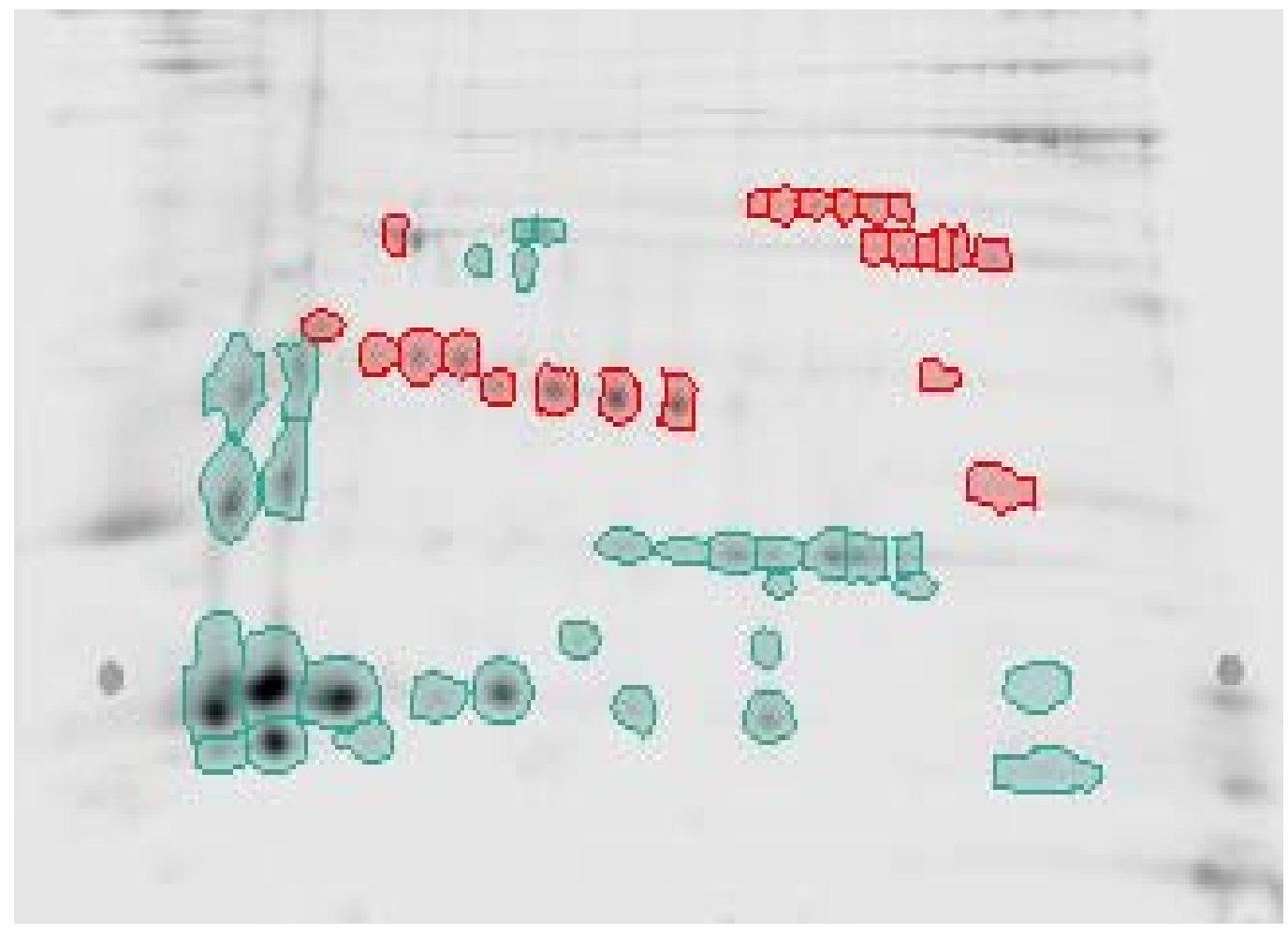

(a) 


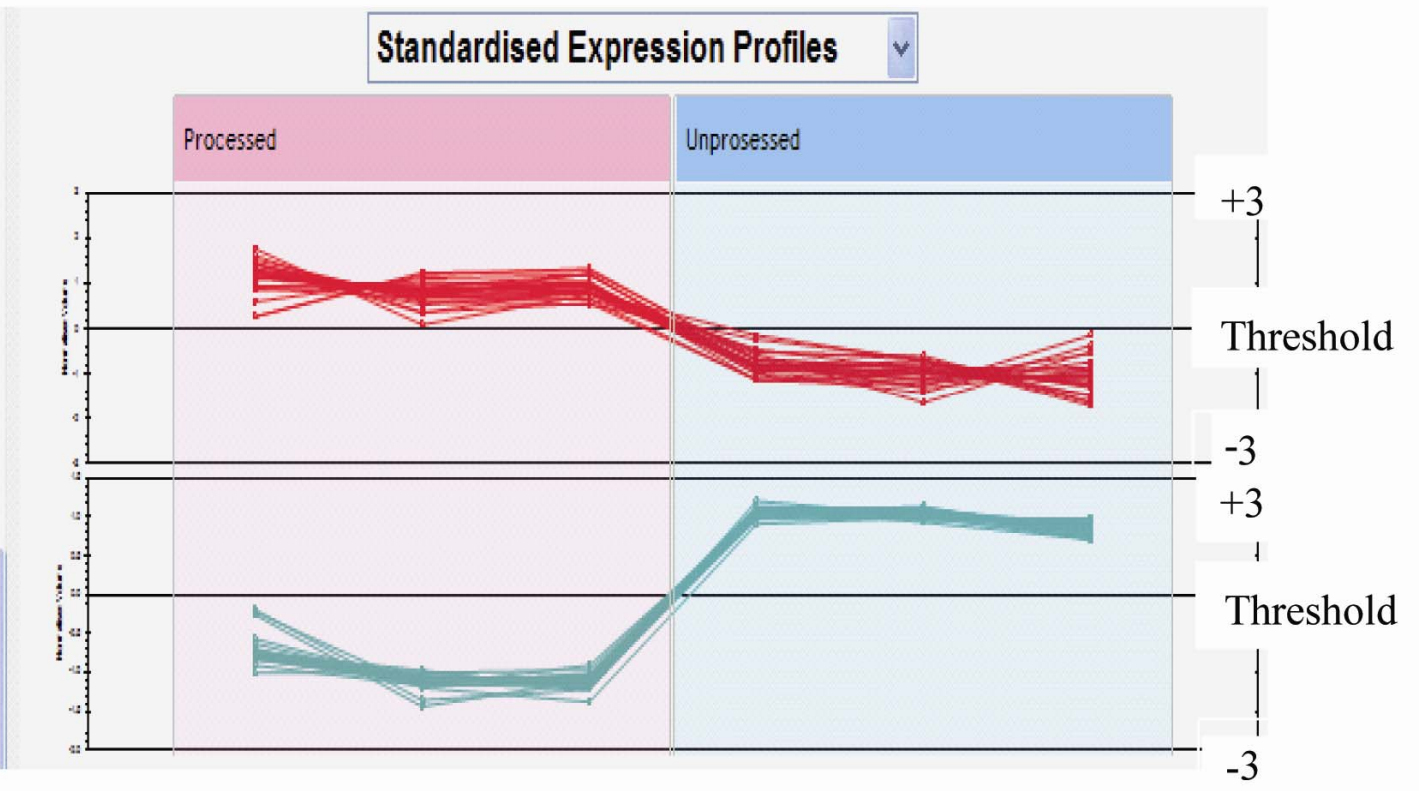

(b)

Figure 2. Cluster analysis of protein expression in seminal plasma of dairy bulls. Reference 2D gel (a) depicting protein spots that differed $(P<0.001)$ and their standard expression profiles $(b)$ in processed (Red outlines) and unprocessed (Green outlines) semen.

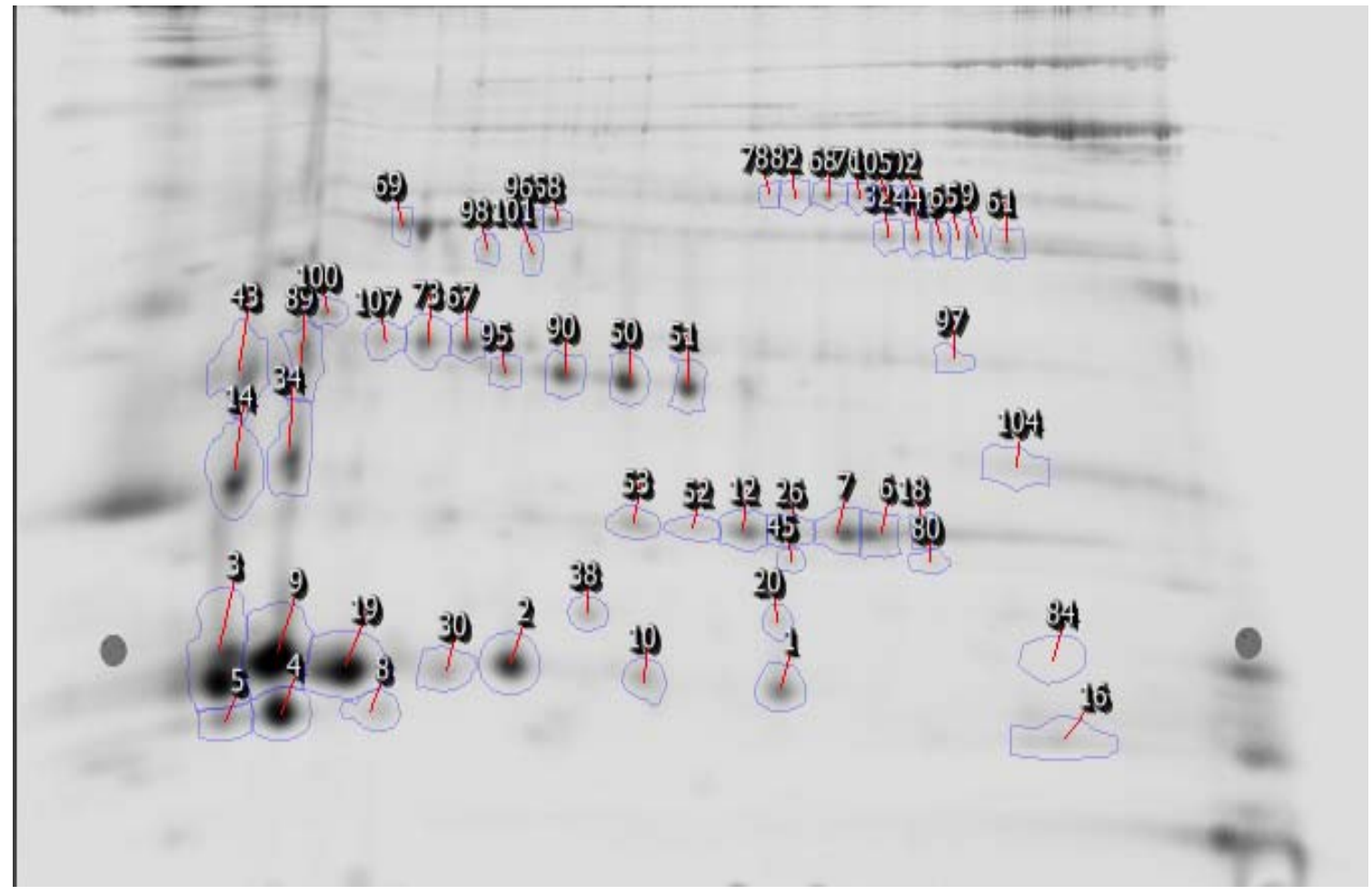

Figure 3. Pick list for protein spots on a reference gel of a pooled internal standard of seminal plasma from processed and unprocessed dairy bull semen. Thirty spots from this list were picked and digested with trypsin for protein identification by CapLC-MS/MS mass spectrometry. 
13 in low fertility bulls [2]. In the present study, seminal plasma protein expression did not differ between high and low fertility dairy bulls. A difference in protein expression between fertility groups had been demonstrated in a previous study [2]. It was anticipated that by utilizing the multiplexing capability of the 2-DIGE technology, experimental errors would be minimized, and a more robust analysis would be achieved as opposed to the densitometric analysis utilized in the former study. The discrepancy in outcome between the two studies can be attributed to sample type utilized or fertility grouping, or both. Samples in the present study were from processed insemination straws and unprocessed seminal plasma from the same ejaculates as opposed to fresh seminal plasma samples utilized in the previous study that avoided secretions from epididymis and vas diferens. Therefore, differential expression of proteins in samples examined in this study might have been affected by sample type as well as semen processing as evidenced by the comparison of processed and unprocessed seminal plasma protein profile. The narrow range of fertility differences in the bulls used in this trial also impeded the classification of semen samples into distinct high and low fertile groups as was done in the previous study [2]. Bulls used in the present study had percentage point deviations (PDs) from the average of $+2.7 \%$ to $-6.5 \%$. In contrast, the previous study had PDs from $+7.7 \%$ to $-18.1 \%$. Consequently, low and high fertility groups in the present study corresponded to the intermediate fertility groups in that study. Because the previous authors reported no differences in expression levels of osteopontin, spermadhesin Z13, phospholipase A2 and BSP $30 \mathrm{kDa}$ among these two groups, it was not surprising that the groups did not differ in their seminal plasma protein profile in the present study. This is a major limiting factor in fertility studies in farm animals because it is rare to find sires at the lower extremes of fertility due selection pressure.

Seminal plasma proteins have been characterized by other investigators and their association with male fertility continues to be explored [2,3,15-17]. Functions of sperm that may be affected by seminal plasma proteins include capacitation, acrosome reaction, motility, DNA integrity and interaction with the oocyte $[3,18]$.

Major BSP proteins (BSP-A1/A2, A3 and BSP-30 $\mathrm{kDa})$ are known to influence capacitation by their ability to modulate membrane cholesterol [18]. Phospholipase A2 (PLA2) and osteopontin are involved in acrosome reaction and sperm-oocyte interaction and possibly early embryonic development [3]. Proteins that might be associated with interaction and modulation of extracellular matrix (ECM) components are TIMP-2, clusterin and cathepsins. These functions may be important during fertilization when the sperm is required to interact with and cross barriers established by the cumulus cells, zona pellucida and oocyte membrane. Albumin, aSFP and clusterin are involved either directly or indirectly in mechanisms aimed at preventing damage to sperm membrane, oxidative stress, and immune attack. Proteins associated with sperm motility in the female reproductive tract include BSP A1/A2, aSFP, PLA2 and ecto 5'-nucleotidase (5'-NT). Spermadhesin Z13 might also be included in the motility associated group because it shares 50\% homology with aSFP. However, expression of spermadhesin Z13 in seminal plasma of dairy bulls was inversely related to fertility [2].

\section{CONCLUSIONS}

Although expression pattern of seminal proteins was not associated with fertility ranking in this study, alteration of protein expression might affect fertility in bulls that show more divergence in fertility ranking. In addition, expression patterns of seminal plasma proteins might be altered during cryopreservation as has been demonstrated in this study. Whether this alteration might affect fertility remains to be explored.

\section{ACKNOWLEDGEMENTS}

The authors acknowledge the support of Select Sires Inc for provision of fertility data and semen samples. We greatly acknowledge the support of Ms. Linda Corrum, Mr. Steve Wolf and Dr. Peter Perotta of the Core Proteomics facility at West Virginia University. This work is published with the approval of the director of the WV Agriculture and Forestry Experiment Station as a scientific paper from the Division of Animal and Nutritional Sciences and was supported by Hatch Project 421, NE1007 and Select Sires grant.

\section{REFERENCES}

[1] Cancel, A.M., Chapman, D.A. and Killian, G.J. (1997) Osteopontin is the 55-kilodalton fertility-associated protein in Holstein bull seminal plasma. Biology of Reproduction, 57, 1293-1301.

[2] Moura, A.A., Koc H., Chapman D.A. and Killian G.J. (2006) Identification of proteins in the accessory sex gland fluid associated with fertility indexes of dairy bulls: a proteomic approach. Journal of Andrology, 27, 201-211. doi:10.2164/jandrol.05089

[3] Moura, A.A., Chapman, D.A. and Killian, G.J. (2007) Proteins of the accessory sex glands associated with the oocyte-penetrating capacity of cauda epididymal sperm from holstein bulls of documented fertility. Molecular Reproduction \& Development, 74, 214-222. doi: $10.1002 / \mathrm{mrd} .20590$

[4] Robertson, S.A. (2007) Seminal fluid signaling in the female reproductive tract: Lessons from rodents and pigs. Journal of Animal Science, 85, E36-44. doi:10.2527/jas.2006-578 
[5] O, W.S., Chen, H.Q. and Chow P.H. (1998) Effects of male accessory sex gland secretions on early embryonic development in the golden hamster. Journal of Reproduction Fertility, 84, 341-344.

[6] Odhiambo, J.F., Poole, D.H., Hughes, L., DeJarnette, M., Inskeep, E.K. and Dailey, R.A. (2009) Pregnancy outcome in dairy and beef cattle after artificial insemination and treatment with seminal plasma or transforming growth factor beta-1. Theriogenology, 72, 566-571. doi:10.1016/j.theriogenology.2009.04.013

[7] O'Leary, S., Robertson, S.A. and Armstrong, D.T. (2002) The influence of seminal plasma on ovarian function in pigs - a novel inflammatory mechanism? Journal of Reproductive Immunology, 57, 225-238.

[8] Lowry, O.H., Rosebrough, N.J., Farr, A. L. and Randall, R.J. (1951) Protein measurement with the Folin-Phenol reagents. The Journal of Biological Chemistry, 193, 265-275.

[9] Koc, E.C., Burkhart, W., Blackburn, K., Koc, H., Moseley, A. and Spremulli L.L. (2001) Identification of four proteins from the small subunit of the mammalian mitochondrial ribosome using a proteomics approach. Protein Science, 10, 471-481.

[10] Thérien, I., Soubeyrand, S. and Manjunath, P. (1997) Major proteins of bovine seminal plasma modulate sperm capacitation by high-density lipoprotein. Biology of Reproduction, 57, 1080-1088. doi:10.1095/biolreprod57.5.1080

[11] Thérien, I., Moreau, R. and Manjunath, P. (1998) Major proteins of bovine seminal plasma and high-density lipoprotein induce cholesterol efflux from epididymal sperm. Biology of Reproduction, 59, 768-776. doi:10.1095/biolreprod59.4.768

[12] Yu, B., Zhao, Y., Zhao, W., Chen, F., Liu, Y., Zhang, J., Fu, W., Zong, Z., Yu, A. and Guan, Y. (2003) The inhibi- tory effect of BSP-A1/-A2 on protein kinase $\mathrm{C}$ and tyrosine protein kinase. Cell Biochemistry and Function, 21, 183-188. doi:10.1002/cbf.1018

[13] Gwathmey, T.M., Ignotz, G.G., Mueller, J.L., Manjunath, P. and Suarez S.S. (2006) Bovine seminal plasma proteins PDC-109, BSP-A3, and BSP-30-kDa share functional roles in storing sperm in the oviduct. Biology of Reproduction, 75, 501-507. doi:10.1095/biolreprod.106.053306

[14] Killian, G.J., Chapman, D.A. and Rogowski, L.A. (1993) Fertility-associated proteins in Holstein bull seminal plasma. Biology of Reproduction, 49, 1202-1207. doi:10.1095/biolreprod49.6.1202

[15] Mortarino, M., Tedeschi, G., Negri, A., Ceciliani, F., Gottardi, L, Maffeo, G. and Ronchi, S. (1998) Two-dimensional polyacrylamide gel electrophoresis map of bull seminal plasma proteins. Electrophoresis, 19, 797801. doi:10.1002/elps.1150190532

[16] Gwathmey, T.M., Ignotz, G.G. and Suarez, S.S. (2003) PDC-109 (BSP-A1/A2) promotes bull sperm binding to oviductal epithelium in vitro and may be involved in forming the oviductal sperm reservoir. Biology of Reproduction, 69, 809-815. doi:10.1095/biolreprod.102.010827

[17] Jobim, M.I., Oberst, E.R., Salbego, C.G., Souza, D.O., Wald, V.B., Tramontina, F. and Mattos, R.C. (2004) Twodimensional polyacrylamide gel electrophoresis of bovine seminal plasma proteins and their relation with semen freezability. Theriogenology, 61, 255-266. doi:10.1016/S0093-691X(03)00230-9

[18] Manjunath, P., Bergeron, A., Lefebvre, J. and Fan, J. (2007) Seminal plasma proteins: Functions and interaction with protective agents during semen preservation. Society of Reproduction and Fertility Supplement, 65, 217-228. 